\title{
Interleukin 10 Induces B Lymphocytes from IgA-deficient Patients to Secrete IgA
}

\author{
F. Brière, ${ }^{\star}$ J-M Bridon, ${ }^{\star}$ D. Chevet, ${ }^{\star}$ G. Souillet, ${ }^{\mathbf{5}}$ F. Bienvenu, ${ }^{5}$ C. Guret, ${ }^{*}$ H. Martinez-Valdez, ${ }^{\star}$ and J. Banchereau ${ }^{*}$ \\ ${ }^{*}$ Schering-Plough, Laboratory for Immunological Research, 69571 Dardilly, France; ${ }^{\ddagger}$ Unité de Néphrologie et Réanimation \\ Métabolique, Hôpital du Bocage, 21034 Dijon, France; and ${ }^{\S}$ Hôpital Debrousse, 69005 Lyon, France
}

\begin{abstract}
We have previously shown that human B lymphocytes cultured in the CD40 system, composed of an anti-CD40 mAb presented by a CD32-transfected fibroblastic cell line, proliferate but do not secrete antibodies. However, the addition of particles of Staphylococcus aureus Cowan (SAC) induces $B$ cell differentiation even in the absence of exogeneous cytokines (CD40/SAC system). Additionally, B lymphocytes cultured in the CD40 system in the presence of human IL10, produce IgM, IgG, and IgA, and Ig levels are further increased by SAC. Here, we have studied the capacity of peripheral blood lymphocytes from patients with IgA deficiency (IgA-D) to secrete Igs, particularly IgA after CD40 triggering. Peripheral blood mononuclear cells (PBMNC) from IgA-D patients cultured in the CD40/SAC system produced IgM and IgG, but not IgA. The addition of IL-10 to the cultures, enhanced the production of IgM and IgG and most strikingly induced the production of high amounts of IgA. The addition of IL-10 to PBMNC from IgA-D patients activated through $\mathrm{CD} 40$ alone resulted in the production of IgA. Thus, SAC and anti-CD40 mAb stimulate B cells to differentiate into cells secreting IgG and IgM whereas IL10 plays a central role in inducing $B$ cells from IgA-D patients to differentiate into IgA secreting cells. ( $J$. Clin. Invest. 1994. 94:97-104.) Key words: IgA deficiency • interleukin$10 \cdot$ B lymphocytes - CD40 triggering - differentiation
\end{abstract}

\section{Introduction}

IgA deficiency, the most common primary immunodeficiency, is known to be a heterogeneous clinical disorder (1). Genetic studies indicate that susceptibility genes located in the major histocompatibility complex class III region may predispose homozygous individuals to this pathology $(2,3)$. Environmental factors may also play a role in the occurence of $\operatorname{IgA}$ deficiency, as several pathologies including viral infections have been found associated with IgA deficiency (1). Although the basic immunologic defect that gives rise to IgA deficiency is unknown, a number of in vitro immunological alterations have been identified. In vitro cell culture studies have revealed that

Address correspondence to F. Brière, Schering-Plough, Laboratory for Immunological Research, 27 chemin des Peupliers, BP 11, 69571, Dardilly, France.

Received for publication 17 September 1993 and in revised form 7 March 1994.

J. Clin. Invest.

(C) The American Society for Clinical Investigation, Inc.

0021-9738/94/07/0097/08 \$2.00

Volume 94, July 1994, 97-104 mechanistically IgA deficiency can be classified into three groups: ( $a$ ) an arrest in the B cell differentiation pathway (4); (b) an increased in suppressor $\mathrm{T}$ lymphocyte function $(5,6)$; and $(c)$ a decrease in helper $T$ lymphocyte function $(6,7)$. It has been proposed that B cells from IgA-D patients have undergone an isotype switch towards IgA since peripheral B cells from these patients bear surface IgA although they do not differentiate into IgA producing cells (8). Recently we developed B cell culture conditions in which an anti-CD40 mAb is presented by a CD32-transfected fibroblast cell line (CD40 system). This system provides the signals for $\mathrm{B}$ cell activation and proliferation, thus allowing us to determine the capacity of cytokines to enhance B cell proliferation and induce Ig synthesis $(9,10)$. In this context, the addition of IL-10 enhances short term B cell proliferation and more strikingly induces $B$ cells to differentiate into high Ig secreting plasma cells (11). The addition of particles of Staphylococcus aureus Cowan $(\mathrm{SAC})^{1}$ to the CD40 system results in considerable secretion of Igs in the absence of isotype switch (CD40/SAC system) (12). Recently a CD40 ligand was identified on activated $\mathrm{T}$ cells and its gene subsequently cloned $(13,14)$. Cells transfected with the gene for CD40 ligand induce B cell activation and proliferation similar to the CD40 system under study in our laboratory (14). The present study is aimed at determining whether different forms of IgA deficiency (acquired and primary) might be related to intrinsic $B$ cell defects or to regulatory $T$ cell abnormalities. In particular, the effects of IL-10 on Ig production by PBMNC or purified B lymphocytes from IgA-D patients was investigated. Here we show that CD40-activated B cells from acquired or primary IgA-D patients can produce IgA when cultured in the presence of IL-10.

\section{Methods}

Patients. Selective acquired IgA deficiency was observed in four patients (BEAU, BIG, ORM, and REB) among a group of 335 adult renal transplant recipients. The clinical and immunologic parameters of these patients have been reported previously (15). These patients had normal Ig serum levels during maintenance hemodialysis and before grafting $(0.8-4 \mathrm{~g} / 1)$. An abrupt decline in IgA serum levels occurred $6 \mathrm{wk}$ after transplantation concurrently with a transient hepatitis. Hepatitis occurred in one chronic hepatitis B (Hbs) carrier patient and in three others with active cytomegalovirus (CMV) disease. Selective IgA deficiency persisted over succeeding years. Immunosuppressive therapy was conventional (anti-thymocyte globulin, azathioprine and low dose corticosteroids)

Two adult patients who had primary IgA deficiency were included in this study: RAF, dialyzed but not transplanted, and BAC who had

1. Abbreviations used in this paper: CVI, common variable immunodeficiency; PBMNC, peripheral blood mononuclear cells; SAC, Staphylococcus aureus Cowan. 


\begin{tabular}{|c|c|c|c|c|}
\hline Patients & Initial disease & Outcome & Sex & Age* \\
\hline & & & & $y r$ \\
\hline \multicolumn{5}{|c|}{ Acquired IgA-D patients } \\
\hline BEAU & Reflux & $\begin{array}{l}\text { Chronic rejection } \\
\text { Tx favorable }\end{array}$ & $\mathbf{F}$ & 40 \\
\hline BIG & Crescentic GN & $\begin{array}{l}\text { Chronic rejection } \\
\text { On dialysis }\end{array}$ & $\mathbf{M}$ & 37 \\
\hline ORM & Membraneous GN & $\begin{array}{l}\text { Arterial thrombosis } \\
\text { On dialysis }\end{array}$ & F & 43 \\
\hline REB & GN & Tx favorable & $\mathbf{M}$ & 61 \\
\hline $\begin{array}{l}\text { Primary IgA-D } \\
\text { Adults }\end{array}$ & \multicolumn{3}{|c|}{ Adults } & \\
\hline RAF & $\begin{array}{l}\text { On dialysis } \\
\text { Not } T x\end{array}$ & & $\mathbf{M}$ & 81 \\
\hline BAC & $\begin{array}{l}\text { Tx } \\
\text { Immunosuppressed }\end{array}$ & Tx favorable & F & 45 \\
\hline \multicolumn{5}{|l|}{ Children } \\
\hline TON & pneumonia & IvIg therapy & $\mathbf{M}$ & 8 \\
\hline ZAR & bronchiectasis & Immunostimulant $^{\ddagger}$ & $\mathbf{M}$ & 4 \\
\hline MAR & $\begin{array}{l}\text { upper respiratory } \\
\text { tract infections }\end{array}$ & $"$ & $\mathbf{M}$ & 12 \\
\hline MARC & bronchiectasis & $"$ & $\mathbf{M}$ & 7 \\
\hline FAS & $\begin{array}{l}\text { upper respiratory } \\
\text { tract infections }\end{array}$ & $"$ & $\mathbf{M}$ & 14 \\
\hline PAV & $\begin{array}{l}\text { upper respiratory } \\
\text { tract infections }\end{array}$ & $"$ & $\mathbf{M}$ & 5 \\
\hline JUS & pneumonia & IvIg therapy & $\mathbf{F}$ & 5 \\
\hline
\end{tabular}

$G N$, glomerulonephritis; $T x$, transplanted. * At the date of the experiments. ${ }^{\ddagger}$ Immunostimulants used were Biostim ${ }^{\circledR}$ or Ribomunyl ${ }^{\circledR}$.

been successfully transplanted and was under immunosuppressive therapy.

In addition, seven children between 4 and 14 years of age (one female and six male), referred in the past two years to the department of Pediatrics for immunologic evaluation for recurrent infections had low serum IgA. Children who had recurrent upper respiratory tract infections were treated by antibiotics and immunostimulatory therapy. Two of the children had I.V.Ig therapy treatment after pneumonia (TON and JUS). All subjects were Caucasian.

Six additional unrelated Caucasian adults (three male and three female) served as controls. Table I shows the significant clinical data available for the two groups of IgA-D patients.

Reagents. The anti-CD40 monoclonal antibody mAb89 was produced in our laboratory (16). The CD32/FC $\gamma \mathrm{RII}$ transfected Ltk- cell line (CD32 L cells) was described earlier (17). Cell phenotypes were determined using anti-CD3,-CD4, -CD8, -CD19, -CD56 (anti-NK cells), and -CD14 (anti-monocytes) FITC conjugated mAbs originating from Becton Dickinson (Mountain View, CA). Purified rhIL-2 (Amgen Biologicals, Thousand Oaks, CA $)\left(3 \times 10^{6} \mathrm{U} / \mathrm{ml}\right)$ and $\mathrm{rhIL}-10$ (Schering-Plough Research Institute Dardilly, France) $\left(1 \times 10^{7} \mathrm{U} / \mathrm{ml}\right)$ were respectively used at $20 \mathrm{U} / \mathrm{ml}$ and $100 \mathrm{ng} / \mathrm{ml}$.

Isolation of cells and culture conditions. Peripheral blood mononuclear cells (PBMNC) were isolated using a standard Ficoll $(d=1,077$ $\mathrm{g} / \mathrm{ml}$ ) gradient method. Peripheral blood B cells were first enriched in the $\mathrm{E}^{-}$fraction and submitted to anti-CD2, anti-CD3, and anti-CD14 mAbs negative selection with magnetic beads coated with anti-mouse IgG (Dynabeads; Dynal, Oslo, Norway) as described previously (18). Finally, unseparated B cells were sorted using a FACSstar ${ }^{\text {plus }}$ flowcytometer (Becton Dickinson) after CD19-FITC labeling. For Ig production, formalinized particles of $S$. aureus strain Cowan I (SAC) pur- chased as Pansorbin from Calbiochem-Behring Corp. (La Jolla, CA) was used as a polyclonal activator at the final concentration of $0.005 \%$ ( vol/vol), either alone or in combination with the CD40 system. The CD40 system is composed of $5 \times 10^{3}$ irradiated (7,000 rad) CD32 L cells and $0.5 \mu \mathrm{g} / \mathrm{ml}$ of anti-CD40 mAb89, where $5 \times 10^{4}$ PBMNC or purified B cells are cultured in a final volume of $200 \mu$ l. Supernatants were harvested after $10 \mathrm{~d}$ and Ig levels were determined by ELISA (19). Cultures were carried out in modified Iscove's medium as detailed previously (19).

Cytokine production. $10^{6} \mathrm{PBMNC}$ of patients and normal donors were incubated in $1 \mathrm{ml}$ culture medium with PHA $(1 \mu \mathrm{g} / \mathrm{ml})$ and SAC and $20 \mathrm{U} / \mathrm{ml}$ of IL-2 for $48 \mathrm{~h}$. Supernatants were harvested and IL-10 and IFN $\gamma$ contents were determined by specific ELISAs described in detail elsewhere $(20,21)$.

\section{Results}

Phenotyping of PBMNC from IgA-D patients. As shown in Table II, the proportion of B cells (stained by CD19 mAb) within the mononuclear cell population was low for all the acquired IgA-D patients (BEAU, BIG, REB, and ORM) as well as the adult primary IgA-D patient RAF. Furthermore, the CD4 compartment was reduced for patients BEAU, BIG, REB, and BAC. All seven children with primary IgA deficiency had normal proportions of $B$ and $T$ lymphocytes when compared with age matched controls. MARC and PAV had reduced percentages of $\mathrm{CD}^{+}{ }^{+} \mathrm{T}$ cells. Serum IgA levels ( Table III) were below $0.08 \mathrm{~g} / 1$ for all patients except BIG who had low but detectable 


\begin{tabular}{|c|c|c|c|c|c|c|}
\hline & CD3 & CD4 & CD8 & CD19 & CD56 & $\mathrm{CD} 14$ \\
\hline \multicolumn{7}{|c|}{$\% *$} \\
\hline \multicolumn{7}{|l|}{ Adults } \\
\hline \multicolumn{7}{|c|}{ Acquired IgA-D patients } \\
\hline BEAU & 38 & 15 & 24 & 2 & 2 & 6 \\
\hline BIG & 30 & 15 & 10 & 1 & 15 & 2 \\
\hline ORM & 60 & 35 & 25 & 3 & 15 & 3 \\
\hline REB & 45 & 10 & 35 & 1 & 10 & 2 \\
\hline \multicolumn{7}{|c|}{ Primary IgA-D patients } \\
\hline RAF & 60 & 35 & 20 & 4 & 25 & 3 \\
\hline BAC & 40 & 15 & 20 & 10 & 3 & 3 \\
\hline Controls $(n=6)$ & $56-82$ & $28-49$ & $9-25$ & $7-16$ & ND & $9-17$ \\
\hline \multicolumn{7}{|l|}{ Children } \\
\hline \multicolumn{7}{|c|}{ Primary IgA-D patients } \\
\hline TON & 70 & 45 & 25 & 13 & 15 & 15 \\
\hline ZAR & 60 & 40 & 20 & 15 & 5 & 5 \\
\hline MAR & 65 & 45 & 25 & 8 & 20 & 15 \\
\hline MARC & 76 & 28 & 43 & 10 & 15 & 15 \\
\hline FAS & 65 & 41 & 24 & 11 & ND & ND \\
\hline PAV & 51 & 25 & 38 & 20 & 32 & 5 \\
\hline JUS & 71 & 41 & 26 & 13 & 17 & 5 \\
\hline
\end{tabular}

* Percent of cells positively stained with the mAbs after isolation on density gradient $(d=1.077)$.

serum IgA levels $(0.16 \mathrm{~g} / 1)$. IgM and IgG levels were within normal range except for patient FAS who had elevated total IgG. The proportion of IgG subclasses varied greatly within this group. Acquired IgA-D patients had lower IgG2 and IgG4 levels whereas within the group of primary IgA-D children, MAR and FAS had increased IgG3 levels compared to normal range reference values (22).

Ig synthesis by PBMNC from IgA-D patients. Purified tonsillar B cells which produce low amounts of Igs when cultured in the CD40 system secrete considerable levels of Igs without isotype switch when particles of SAC are supplemented (12). Thus, to maximize B cell differentiation we tested the production of Igs by PBMNC cultured in the CD40 system together with SAC. As shown in Table IV, PBMNC from controls produced IgG $(14.5 \mu \mathrm{g} / \mathrm{ml}), \operatorname{IgM}(19 \mu \mathrm{g} / \mathrm{ml})$ and $\operatorname{IgA}(5.2 \mu \mathrm{g} /$ $\mathrm{ml}$ ) when cultured under these conditions (mean obtained with six samples of PBMNC from normal donors). PBMNC from controls cultured with either SAC or the CD40 system alone produced between 0.1 and $0.7 \mu \mathrm{g} / \mathrm{ml}$ of the different isotypes (not shown). PBMNC from IgA-D patients cultured in the CD40 system together with SAC secreted IgG (mean of 2.3 and $3 \mu \mathrm{g} / \mathrm{ml}$ for acquired IgA-D and primary IgA-D, respectively) and IgM (mean of 2 and $5.3 \mu \mathrm{g} / \mathrm{ml}$ for acquired $\operatorname{IgA}$ $\mathrm{D}$ and primary $\operatorname{IgA}-\mathrm{D}$, respectively). The mean production of IgG was around 4-5-fold less than that of controls while that of IgM was 4-10-fold lower than that of controls. No detectable levels of $\operatorname{IgA}(<0.01 \mu \mathrm{g} / \mathrm{ml})$ could be found in supernatants of IgA-D PBMNC, whereas normal donors produced as much as $5.2 \mu \mathrm{g} / \mathrm{ml}$ IgA. Thus mononuclear cells from IgA-D patients are unable to produce IgA while they secrete quite significant levels of IgM and IgG after CD40/SAC triggering. These data provide in vitro confirmation of the diagnosis of $\operatorname{IgA}$ deficiency (Table III).

$I L-10$ induces IgA synthesis by PBMNC from IgA-D patients. As IL-10 has earlier been found to induce CD40-activated naive B cells to produce small amounts of $\operatorname{IgA}(12)$, we explored whether it would induce B cells from patients with IgA$\mathrm{D}$ to produce IgA. Thus, PBMNC from the 13 IgA-D patients were cultured in the CD40/SAC system and in the presence of IL-10. As shown in Fig. 1, PBMNC from IgA-D patients activated by anti-CD40 mAb and SAC secreted IgA when IL-10 was added to cultures. The levels of IgA obtained varied from one patient to another. The quantities of $\operatorname{IgA}$ produced by the PBMNC from acquired IgA-D patients (Fig. $1 A$ ) ranged from 0.3 to $1.6 \mu \mathrm{g} / \mathrm{ml}$ of IgA. Even more strikingly, PBMNC from primary IgA-D patients (Fig. $1 B$ ) secreted up to $7.9 \mu \mathrm{g} / \mathrm{ml}$ IgA in response to IL-10. While the mean IgA levels obtained with IgA-D PBMNC in response to IL-10 (mean \pm SD $=3 \pm 2.6$ $\mu \mathrm{g} / \mathrm{ml} \operatorname{IgA}, n=13 \mathrm{IgA}-\mathrm{D}$ patients ) was lower than of controls (Fig. $1 C)($ mean $\pm \mathrm{SD}=10.8 \pm 2.4 \mu \mathrm{g} / \mathrm{ml} \mathrm{IgA}, n=6$ controls $)$, it is noteworthy that some IgA-D patients produced as much IgA as controls.

As can be seen in Fig. 2, the effect of IL-10 was not restricted to IgA isotype. Addition of IL-10 also increased IgG (25-fold) and IgM (3-10-fold) productions by activated PBMNC from normal donors and IgA-D patients. Cells from primary IgA-D patients produced almost as much IgG and IgM as controls, while those from acquired IgA-D produced less Ig. This may be related to the lower B cell numbers in acquired IgA-D patients (Table II). As shown in Fig. 3, IL-10 increased IgA secretion by PBMNC of both IgA-D patients (ZAR and MAR) and controls in a dose-dependent fashion. Significant IgA syn- 


\begin{tabular}{|c|c|c|c|c|c|c|c|}
\hline Donors & $\operatorname{IgG}$ & $\operatorname{IgA}$ & IgM & $\operatorname{IgG} 1$ & $\operatorname{IgG} 2$ & $\operatorname{IgG} 3$ & IgG4 \\
\hline Adults & & & & $g n$ & & & \\
\hline \multicolumn{8}{|c|}{$\begin{array}{l}\text { Group I: acquired IgA deficient } \\
\text { patients* }\end{array}$} \\
\hline BEAU & 12 & $<0.08$ & 2.77 & 6.5 & 0.2 & 0.26 & 0.01 \\
\hline BIG & 15.5 & 0.16 & 1 & 5.85 & 0.35 & 0.15 & 0.01 \\
\hline ORM & 15.9 & $<0.08$ & 1.34 & 13 & 0.1 & 0.75 & 0.05 \\
\hline REB & 6.9 & $<0.08$ & 0.37 & 4.8 & 0.3 & 0.15 & 0.04 \\
\hline \multicolumn{8}{|c|}{$\begin{array}{l}\text { Group II: inherited IgA deficient } \\
\text { patients* }\end{array}$} \\
\hline RAF & 18 & $<0.08$ & 2.44 & & & & \\
\hline BAC & 12.2 & $<0.08$ & 3.1 & & & & \\
\hline \multicolumn{8}{|l|}{ Reference values } \\
\hline normal controls & $8-16$ & $0.8-4$ & $1-3$ & $3.2-12$ & $1.2-3.5$ & $0.2-0.8$ & $0.2-0.7$ \\
\hline \multicolumn{8}{|l|}{ Children } \\
\hline \multicolumn{8}{|c|}{$\begin{array}{l}\text { Group II: inherited IgA deficient } \\
\text { patients* }\end{array}$} \\
\hline TON & 15.9 & $<0.08$ & 1.58 & 9.6 & 1.3 & 0.38 & 0.52 \\
\hline ZAR & 18.3 & $<0.08$ & 1.92 & 12 & 2.2 & 0.19 & 0.2 \\
\hline MAR & 11.1 & $<0.08$ & 0.95 & 7.2 & 3.2 & 1 & 0.4 \\
\hline MARC & 11 & $<0.08$ & 0.82 & 9.4 & 1.8 & 0.4 & 0.28 \\
\hline FAS & 23.4 & $<0.08$ & 2.29 & 18.8 & 3.2 & 2.14 & $<0.02$ \\
\hline PAV & 16.3 & $<0.08$ & 1.01 & 12.5 & 0.9 & 0.3 & 0.17 \\
\hline JUS & 13.6 & $<0.08$ & 1.75 & 10.3 & 3.1 & 0.27 & 0.21 \\
\hline \multicolumn{8}{|c|}{$\begin{array}{l}\text { Reference values } \\
\text { normal controls (age in years) }\end{array}$} \\
\hline $4-8$ & $5-14$ & $0.5-2.2$ & $0.5-2$ & $3.8-12$ & $0.4-3$ & $0.2-0.6$ & $0.1-0.8$ \\
\hline $8-10$ & $"$ & $"$ & $"$ & $4.9-11$ & $0.5-3$ & $0.2-0.6$ & $0.2-0.7$ \\
\hline $10-13$ & $"$ & $"$ & $"$ & $3.6-11$ & $0.5-3$ & $0.2-0.6$ & $0.3-0.7$ \\
\hline
\end{tabular}

* Mean of 3-5 determinations over 2 yr preceeding the experiments. Seric Ig contents were determined by nephelometry.

thesis could be detected with $10 \mathrm{ng} / \mathrm{ml}$ of IL-10 and maximum IgA synthesis was obtained with $100 \mathrm{ng} / \mathrm{ml}$ of IL-10.

$I L-10$ directly acts on $B$ cells from IgA-D patients. Whenever the sample size allowed it, to determine whether IL-10 directly acts on B lymphocytes, these were purified from blood mononuclear cells by FACS-sorting CD19 positive cells (95\% purity). B cells were then cultured with or without IL-10 in the CD40/SAC system. As shown in Fig. 4, highly purified B cells from two children with primary IgA deficiency (ZAR and JUS) produced IgA in response to IL-10. As observed earlier with IgA-D PBMNC, IL-10 enhanced the production of IgG and IgM by purified $B$ cells of these IgA-D patients (Fig. 4). In control experiments, incubation of patient PBMNC with the anti-CD19 mAb alone did not alter the subsequent Ig production (data not shown).

To discriminate the relative contribution between SAC, antiCD40 mAb and IL-10 on Ig synthesis, we cultured PBMNC from primary IgA-D patients (TON, ZAR, and MAR) with SAC in the presence or absence of IL-10, or anti-CD40 mAb plus SAC without or with IL-10. As shown in Table V, PBMNC activated with SAC did not result in $\operatorname{IgA}$ production even in the presence of IL-10. Also, triggering of PBMNC by antiCD40 mAb alone was not sufficient to induce IgA synthesis. However, addition of IL-10 to CD40-triggered PBMNC resulted in the production of $\operatorname{IgA}$. Finally, addition of SAC augmented the effect of IL-10 on Ig synthesis when PBMNC were cultured in the CD40 system (6-19-fold increased IgA levels with antiCD40 mAb/SAC plus IL-10 compared with anti-CD40 mAb plus IL-10). Thus, anti-CD40 and SAC stimulated B cells to differentiate into cells secreting IgG and IgM (Table IV), whereas IL-10 was instrumental in inducing B cells of IgA-D patients to differentiate into IgA secreting cells.

$P B M N C$ from IgA-D patients produce IL-10. Because IL10 efficiently restores the defective $\operatorname{IgA}$ production by the $\mathrm{B}$ cells of patients with IgA-D, we explored the possibility that this pathology may be associated with altered IL-10 production. However, as shown in Fig. 5, PBMNC from IgA-D patients activated with SAC, PHA and IL-2 (21) produced significant levels of IL-10, ranging from $0.5-1.8 \mathrm{ng} / \mathrm{ml}$ (mean $\pm \mathrm{SD}$ $=1.1 \pm 0.5)$. Note, this amount of IL-10 is significantly lower ( $P=0.0019$, Mann and Withney $\mathrm{U}$ test $)$ than that obtained with normal control PBMNC (mean $\pm \mathrm{SD}=2.8 \pm 0.5)$. At the end of cultures, levels of IL-10 produced by PBMNC in response to anti-CD40 mAb/SAC activation were in the order of $500 \mathrm{pg} / \mathrm{ml}$ with no significant differences noted between IgAD patients and controls (not shown).

Next, we explored whether the reduced production of IL10 by cells from IgA-D patients could be due to increased 
Table IV. Ig Production by PBMNC from Normal Donors and IgA-D Patients in Response to SAC and Anti-CD4O

\begin{tabular}{|c|c|c|c|}
\hline & IgG & $\operatorname{Ig} \mathrm{A}$ & $\lg M$ \\
\hline & & $\mu g / m l$ & \\
\hline \multicolumn{4}{|l|}{ Controls } \\
\hline 1 & $15.3 \pm 1.9$ & $7.3 \pm 1.5$ & $19.7 \pm 2$ \\
\hline 2 & $19.5 \pm 2$ & $6 \pm 1$ & $13.8 \pm 0.6$ \\
\hline 3 & $3.6 \pm 0.5$ & $4 \pm 0.5$ & $19 \pm 1.6$ \\
\hline 4 & $9.6 \pm 2$ & $4.5 \pm 0.5$ & $7.1 \pm 1$ \\
\hline 5 & $28.8 \pm 2.1$ & $5.2 \pm 0.9$ & $19.6 \pm 2$ \\
\hline 6 & $9.7 \pm 1.9$ & $4 \pm 0.3$ & $35.6 \pm 4$ \\
\hline Mean $\pm \mathrm{SD}$ & $14.5 \pm 8$ & $5.2 \pm 1.2$ & $19.0 \pm 8.6$ \\
\hline \multicolumn{4}{|c|}{ Acquired IgA-D patients } \\
\hline BEAU & $3.3 \pm 0.3$ & $<0.01$ & $3.7 \pm 0.8$ \\
\hline $\mathrm{BIG}$ & $0.6 \pm 0.1$ & $<0.01$ & $0.6 \pm 0.1$ \\
\hline REB & $3.7 \pm 0.2$ & $<0.01$ & $1.6 \pm 0.1$ \\
\hline ORM & $1.8 \pm 0.6$ & $<0.01$ & $2.2 \pm 0.5$ \\
\hline Mean $\pm S D$ & $2.3 \pm 1.2$ & & $2.0 \pm 1.1$ \\
\hline \multicolumn{4}{|c|}{ Primary IgA-D patients } \\
\hline RAF & $1.4 \pm 0.3$ & $<0.01$ & $14 \pm 1.5$ \\
\hline $\mathrm{BAC}$ & $6 \pm 0.9$ & $<0.01$ & $3.3 \pm 0.1$ \\
\hline TON & $4.2 \pm 0.2$ & $<0.01$ & $2.1 \pm 0.4$ \\
\hline ZAR & $11.5 \pm 1.5$ & $<0.01$ & $13.6 \pm 1.7$ \\
\hline MAR & $1.7 \pm 0.4$ & $<0.01$ & $8.4 \pm 1$ \\
\hline MARC & $1.5 \pm 0.3$ & $<0.01$ & $2.7 \pm 0.5$ \\
\hline FAS & $0.2 \pm 0.03$ & $<0.01$ & $2 \pm 0.1$ \\
\hline PAV & $0.13 \pm 0.02$ & $<0.01$ & $1 \pm 0.2$ \\
\hline JUS & $0.2 \pm 0.03$ & $<0.01$ & $0.9 \pm 0.05$ \\
\hline Mean \pm SD & $3.0 \pm 3.5$ & & $5.3 \pm 5$ \\
\hline
\end{tabular}

$5 \times 10^{4}$ PBMNC were cultured on $5 \times 10^{3}$ irradiated CDw32 L cells with $0.5 \mu \mathrm{g} / \mathrm{ml}$ anti-CD40 mAb (mAb89) and SAC. Ig levels $(\mu \mathrm{g} / \mathrm{ml})$ were determined after a 10-d culture period. Data are expressed as mean $\pm \mathrm{SD}$ values of triplicate cultures.

synthesis of IFN $\gamma$, an antagonist of IL-10 production (23). However, following activation, PBMNC from IgA-D patients produced levels of IFN $\gamma$ comparable with those obtained with controls $(P>0.05)$ (Fig. 5). IL-2 and IL-4 levels were also comparable in both groups (data not shown) thus excluding a clear-cut disequilibrium in the production of those cytokines.

\section{Discussion}

In the present study, we have induced B lymphocytes from IgA$D$ patients to secrete $\operatorname{IgA}$ in response to a combination of three well known B cell activators: anti-CD40 antibody, particles of SAC and interleukin 10. This combination of activators was particularly efficient as cells from all $\operatorname{Ig} A-D$ patients tested were induced to produce IgA, irrespective of whether patients had acquired or primary IgA deficiency. However, cells from primary IgA-D patients produced more IgA than those from acquired IgA-D patients. In this context, cells from acquired IgAD patients also produced less $\operatorname{IgM}$ and $\operatorname{IgG}$ than those from primary IgA-D patients or controls. This observation correlates with the fact that the acquired IgA-D patients had very low numbers of circulating B lymphocytes, which may be related to their undergoing dialysis over an extensive period of time. Within the group of primary IgA-D patients, $3 / 9$ produced low
A ACQUIRED IgA-D PATIENTS
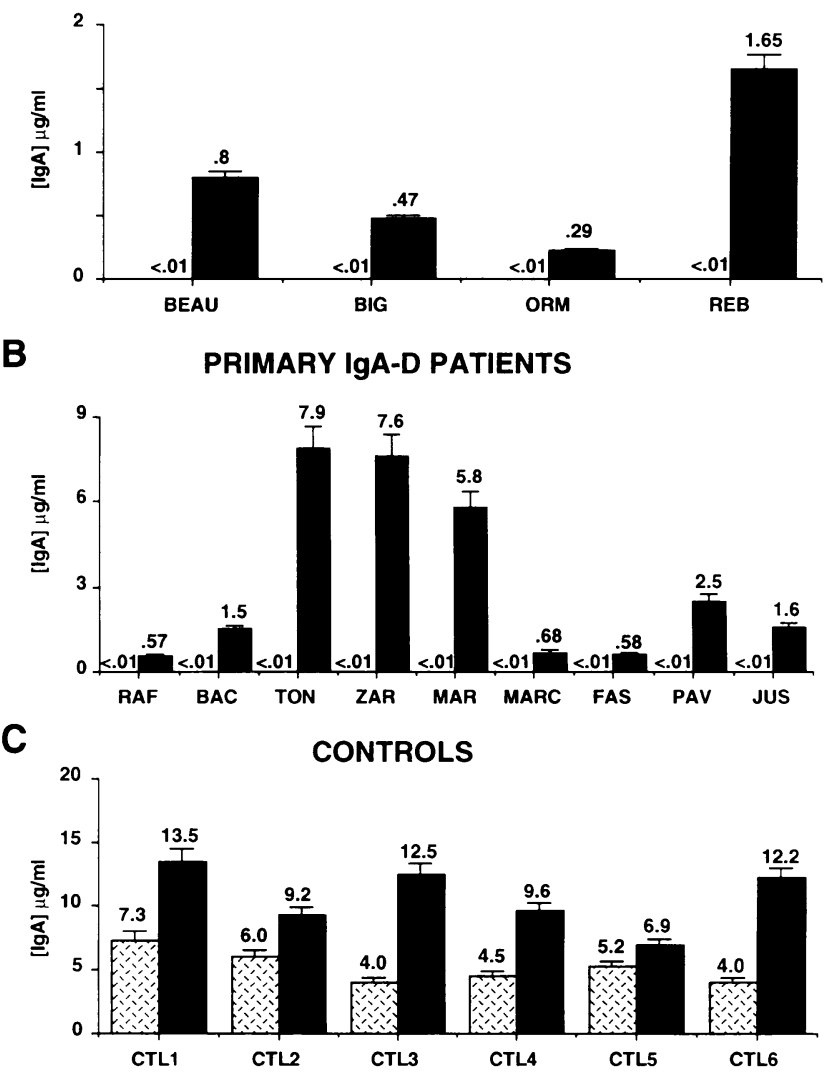

Figure 1. IL-10 induces IgA production by PBMNC from IgA-D patients. $5 \times 10^{4}$ PBMNC from acquired or primary IgA-D patients and normal donors were cultured on $5 \times 10^{3}$ irradiated CDw32 L cells with $0.5 \mu \mathrm{g} / \mathrm{ml} \mathrm{mAb89}$ and SAC $(0.005 \% \mathrm{vol} / \mathrm{vol})$ with ( $)$ or without (匚) $100 \mathrm{ng} / \mathrm{ml} \mathrm{IL-10.} \mathrm{Culture} \mathrm{supernatants} \mathrm{were} \mathrm{harvested} \mathrm{after} 10 \mathrm{~d}$ in culture. IgA levels $(\mu \mathrm{g} / \mathrm{ml})$ are expressed as mean \pm SD values of triplicate cultures.

levels of $\operatorname{IgA}$ in response to IL-10 (reaching $6 \%$ of controls), while the majority of primary IgA-D cells $(6 / 9)$ produced nearly normal amounts of IgA in this system (20-80\% of controls). None of the patients included in this study were asymptomatic, thus further studies are required to assess whether the levels of $\operatorname{Ig}$ A obtained in this system are comparable in asymptomatic IgA-D cells with those obtained with $\operatorname{IgA}$-D patients suffering of recurrent infections.

Because of limited sample size, most of our study was performed with whole blood mononuclear cells. However, we were able to purify B lymphocytes from two primary IgA-D patients (ZAR and JUS) which IgA secretion by PBMNC reached nearly normal amounts in response to IL-10. Highly purified blood $\mathrm{B}$ cells ( $95 \%$ pure) from those primary IgA-D patients were also induced to secrete levels of IgA comparable to those of normal donors. It is unlikely that the remaining $5 \%$ contaminant nonB cells may play an indirect role in the effect of IL-10 on IgA synthesis. Also, we have reported previously that $\operatorname{sIgD}+$ naive B cells ( $>98 \%$ pure) isolated from tonsils secreted low but reproducible levels of $\mathrm{IgA}$ in response to $\mathrm{IL}-10$ when activated through CD40 ( 12 ). However, it is not known whether CD40 triggering and/or addition of IL-10 enhances the production of $\operatorname{TGF} \beta$ which has been reported to induce switch at a molecular 

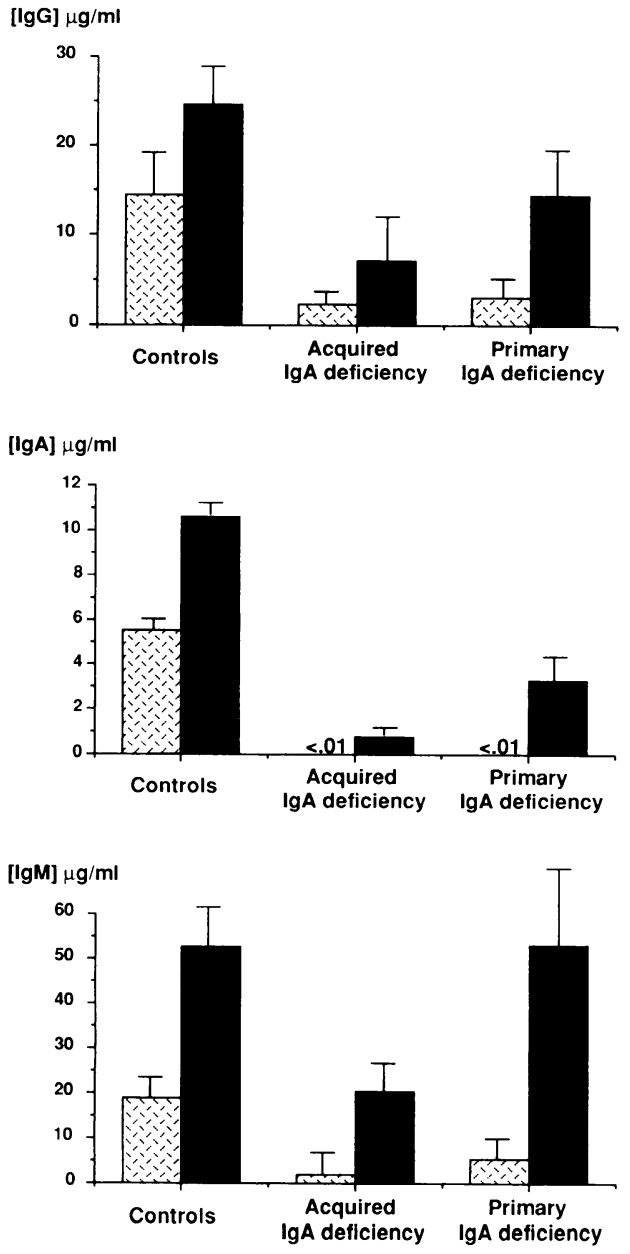

Figure 2. IL-10 enhances $\operatorname{IgG}, \operatorname{IgA}$, and $\operatorname{IgM}$ in PBMNC from both controls and IgA-D patients. $5 \times 10^{4} \mathrm{PBMNC}$ from acquired or primary IgA-D patients and normal donors were cultured on $5 \times 10^{3}$ irradiated CDw32 L cells with $0.5 \mu \mathrm{g} / \mathrm{ml} \mathrm{mAb89}$ and SAC $(0.005 \% \mathrm{vol} / \mathrm{vol})$ with $(\square)$ or without (口) $100 \mathrm{ng} / \mathrm{ml}$ IL-10. Culture supernatants were harvested after $10 \mathrm{~d}$ of culture and Ig levels $(\mu \mathrm{g} / \mathrm{ml})$ were measured by ELISA. Results are expressed as mean \pm SD of experiments obtained with normal donors PBMNC $(n=6)$, PBMNC from acquired IgA-D $(n=4)$, and primary IgA-D patients $(n=9)$. [lg] $\mu \mathrm{g} / \mathrm{ml}$

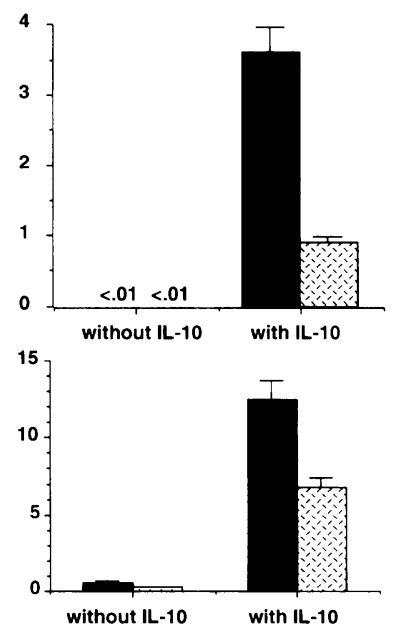

$\lg A$

Figure 4. IL-10 induces $B$ cells from IgA-D patients to produce $\operatorname{IgA} .5$ $\times 10^{4}$ anti-CD19 FACS sorted B cells ( $95 \%$ pure) from two primary IgA-D patients (ZAR, and JUS, $\square$ ) were cultured on $5 \times 10^{3}$ irradiated CDw32 L cells with $0.5 \mu \mathrm{g} / \mathrm{ml} \mathrm{mAb89}$ and SAC $(0.0) 5 \% \mathrm{vol} / \mathrm{vol})$ with or without $100 \mathrm{ng} /$ $\mathrm{ml}$ IL-10. Culture supernatants were harvested after $10 \mathrm{~d}$ of culture and Ig levels $(\mu \mathrm{g} / \mathrm{ml})$ are expressed as mean $\pm \mathrm{SD}$ values of triplicate cultures.

level (24). Nevertheless, the combination of the three activators (anti-CD40 mAb/SAC/IL-10) specifically targets the B cells within the mononuclear cell preparation. The combination of anti-CD40 $\mathrm{mAb}$ and IL-10 appeared to be the minimal combination to overcome the differentiation arrest of $\operatorname{IgA}$-committed cells in these patients as shown by low levels of $\operatorname{IgA}$ in supernatants of cells stimulated with these two signals. The addition of SAC with these two signals essentially results in an amplification of the Ig secretion. It is important to note that a combination of anti-CD40 mAb and SAC permits normal B cells to produce large amounts of $\operatorname{IgM}$, $\operatorname{IgG}$ and $\operatorname{IgA}$, and $\operatorname{IgA}-\mathrm{D} B$ cells to produce only IgM and IgG but not IgA. Taken together, these results indicate that the addition of IL-10 is a crucial event for the release of the $\operatorname{IgA}$ blockade in these patients.

The capacity of CD40 triggering and IL-10 to restore in

$[\operatorname{lgA}] \mu \mathbf{g} / \mathrm{ml}$

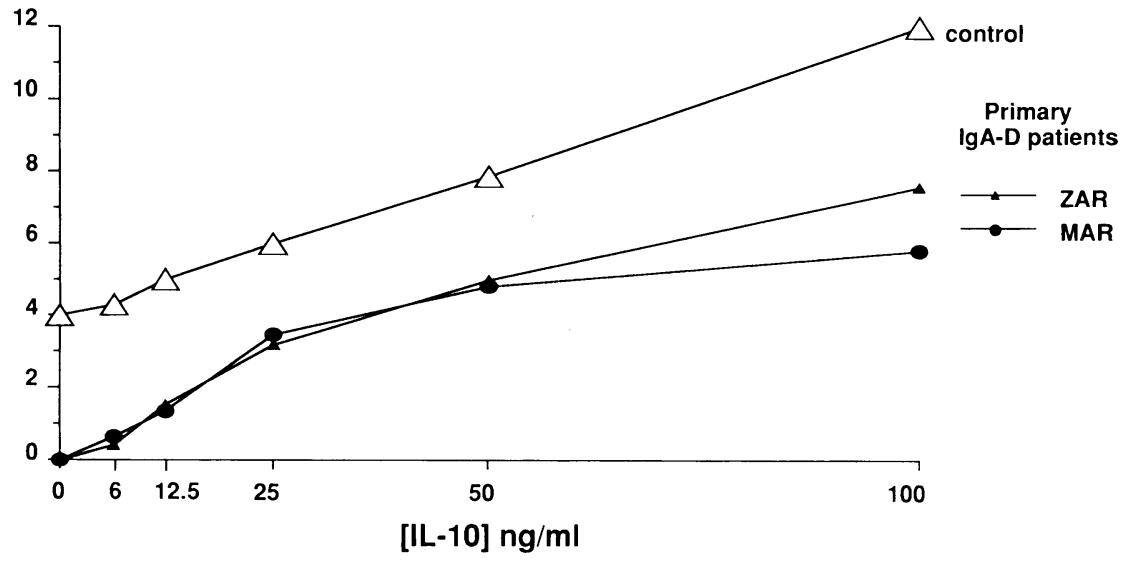

Figure 3. IL-10 induces dose-dependent $\lg \mathrm{A}$ synthesis. $5 \times 10^{4}$ PBMNC from primary IgA-D patients (ZAR and MAR) and normal donors ( mean of data obtained with 6 controls) were cultured on $5 \times 10^{3}$ irradiated CDw32 L cells with $0.5 \mu \mathrm{g} / \mathrm{ml} \mathrm{mAb89}$ and SAC $(0.005 \% \mathrm{vol} / \mathrm{vol})$ with or without increasing concentrations of IL-10. Culture supernatants were harvested after $10 \mathrm{~d}$ of culture and $\operatorname{IgA}$ levels $(\mu \mathrm{g} / \mathrm{ml})$ are expressed as mean $\pm S D$ values of triplicate cultures. 
Table V. Respective Contribution of SAC, Anti-CD40 and IL-10 on Ig Synthesis by PBMNC from IgA-D Patients

\begin{tabular}{|c|c|c|c|c|c|c|c|c|}
\hline \multirow[b]{2}{*}{ Patients } & \multirow{2}{*}{$\begin{array}{l}\text { Anti- } \\
\text { CD40 }\end{array}$} & \multirow[b]{2}{*}{ SAC } & \multicolumn{2}{|c|}{$\operatorname{IgG}$} & \multicolumn{2}{|c|}{ IgA } & \multicolumn{2}{|c|}{ IgM } \\
\hline & & & - & IL-10 & - & IL-10 & - & IL-10 \\
\hline & & & & & $\mu g / m l$ & & & \\
\hline \multicolumn{9}{|l|}{ TON } \\
\hline & - & + & .13 & .15 & $<.01$ & $<.01$ & .05 & .05 \\
\hline & + & - & .2 & .5 & $<.01$ & .2 & .1 & 5.1 \\
\hline & + & + & 4.2 & 30.5 & $<.01$ & 2.4 & 2.1 & 65.2 \\
\hline \multicolumn{9}{|l|}{ ZAR } \\
\hline & + & - & .4 & 10.2 & $<.01$ & 1.3 & 0.7 & 49.4 \\
\hline & + & + & 11.5 & 28.7 & $<.01$ & 7.5 & 13.6 & 104.8 \\
\hline \multicolumn{9}{|l|}{ MAR } \\
\hline & + & - & .15 & 4.1 & $<.01$ & 0.3 & 0.1 & 5.3 \\
\hline & + & + & 1.7 & 8.9 & $<.01$ & 5.8 & 8.4 & 112.5 \\
\hline
\end{tabular}

$5 \times 10^{4} \mathrm{PBMNC}$ were cultured with or without SAC, in the presence or absence of $5 \times 10^{3}$ irradiated CDw32 L cells and $0.5 \mu \mathrm{g} / \mathrm{ml}$ anti-CD40 $\mathrm{mAb}(\mathrm{mAb} 89)$ and with or without $100 \mathrm{ng} / \mathrm{ml} \mathrm{IL-10.} \mathrm{Ig} \mathrm{levels}(\mu \mathrm{g} / \mathrm{ml})$ were determined after a 10-d culture period. Data are expressed as mean \pm SD of triplicate cultures.

vitro Ig production is further illustrated by recent studies on B cells from patients with common variable immunodeficiency (CVI). We and other groups have reported that B cells from most CVI patients can be induced to secrete isotypes such as IgG and IgA in the presence of anti-CD40 mAb and IL-10 (2527 ) or IgE in response to anti-CD40 mAb and IL-4 (27). Both pathologies, CVI and IgA-D are heterogeneous groups of disorders characterized by defective antibody production. It has been suggested that IgA deficiency and CVI may represent the extremes of the spectrum of a common B cell defect, thus it will

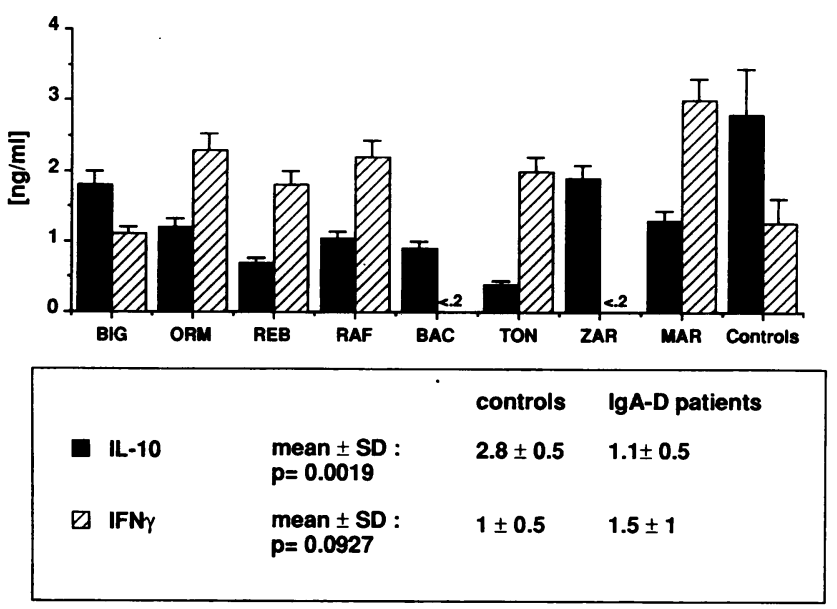

Figure 5. PBMNC from IgA-D patients produce low levels of IL-10 (匹) and normal levels of IFN $\gamma(\square) .10^{6}$ PBMNC from IgA deficient patients were incubated with SAC $(0.005 \% \mathrm{vol} / \mathrm{vol}), 1 \mu \mathrm{g} / \mathrm{ml}$ PHA and $20 \mathrm{IU} / \mathrm{ml} \mathrm{IL-2}$. Supernatants were harvested after $48 \mathrm{~h}$, hIL-10 and IFN $\gamma$ contents were measured by specific ELISAs. Results are expressed as mean \pm SD values of triplicate cultures. A Mann and Withney $U$ test was used to compare the levels of IL-10 and IFN $\gamma$ obtained in supernatants of activated PBMNC from IgA-D patients with those obtained from normal donors. The level of significance of the statistical analysis was $<0.05$. be of interest to further dissect the contribution of CD40 and cytokines in the release of a given B cell defect. Furthermore, the capacity or the failure of those signals to restore an effective antibody synthesis, will probably permit us to better identify subgroups of patients within the groups of IgA-D and CVI.

Earlier studies have shown that naive $\operatorname{sIgD}^{+}$human B lymphocytes produce low amounts of $\operatorname{IgA}$ in response to IL-10 and that TGF $\beta$ strongly enhances this effect (12). Furthermore, treatment of mice with anti-IL-10 antibodies results in a strong decrease of circulating IgM and IgA (28). It was thus tempting to hypothesize that IgA-D patients may suffer either from a deficit of IL-10 production or from the presence of an IL-10 antagonist. However, mononuclear cells from IgA-D patients were found to produce IL-10 after optimal activation with SAC and PHA, although the levels were slightly lower than those of normal controls. Also, the production of IFN $\gamma$ which has been shown to antagonize the production of IL-10 (23) was comparable with that obtained with normal donor cells. Levels of IL10 synthesis induced in SAC and anti-CD40 mAb cultures were low but comparable with normal individuals and IgA-D patients. The fact that a number of cytokines were present in supernatants of activated cells did not allow us to determine whether the IL10 of IgA-D patients was biologically active. As neutralizing circulating antibodies against IL1 $\alpha$ (29), IL-2 (30), IL-6 (31), and IFN $\gamma$ (32) have been described, the presence of anti-IL10 antibodies was investigated. While anti-IL-10 antibodies could be found in some rare individuals ( $C$. Caux-Ménétrier and F. Brière, manuscript in preparation), they could not be detected in the serum of the $13 \operatorname{IgA}-\mathrm{D}$ patients tested. Our future studies will aim at determining whether primary $\operatorname{IgA-D}$ patients display functional IL-10 or whether they have an IL-10 antagonist such as soluble IL-10 receptor. This would appear particularly relevant for IgA deficiency associated with IgG1 and IgG3 deficiencies (33) since we recently found that IL-10 induces naive $\mathrm{sIgD}^{+} \mathrm{B}$ cells to specifically produce these IgG subclasses (34). Alternatively, these patients may have a blockade in IL-10 production at the physiological sites of $B$ cell differentiation into plasma cells, namely the bone marrow and/or the mucosal lamina propria. 
The present study provides a framework for an understanding of the defect underlying the heterogeneous nature of $\operatorname{IgA}$ deficiency. In particular, unraveling the molecular mechanisms controlling IL-10-induced differentiation of normal B cells may eventually permit us to understand the basis for the differentiation blockade of IgA-committed B cells in IgA-D patients. In this context, the possibility of a defective CD40 ligand was ruled out, as activated $T$ cells of $\operatorname{IgA}-\mathrm{D}$ patients express the CD40 ligand which bound a CD40-Fc fusion protein (data not shown). This was indeed expected because patients with altered CD40 ligand are unable to mount isotype switch (35-38).

In conclusion, the present study indicates that the combination of anti-CD40 mAb, SAC and IL-10 induces B cells from IgA-D patients to produce considerable amounts of $\operatorname{IgA}$. Thus, IL-10 appears to be critical in releasing the differentiation blockade of IgA-committed B cells.

\section{Acknowledgments}

We gratefully acknowledge the expert editorial assistance of $\mathrm{N}$. Courbière, S. Ho, and S. Saeland for critical reading of the manuscript.

\section{References}

1. Schaffer, F. M., R. C. Monteiro, J. E. Volanakis, and M. D. Cooper. 1991. IgA deficiency. Immunodefic. Rev. 3:15-44.

2. Wilton, A. N., T. J. Cobain, and R. I. Dawkins. 1985. Family studies in IgA deficiency. Immunogenetics. 21:333-342.

3. Volanakis, J. E., Z.-B. Zhu, F. M. Schaffer, K. J. Macon, J. Palermos, B. O. Barger, R. Go, R. D. Campbell, H. W. Schroeder, and M. D. Cooper. 1992. Major histocompatibility complex class III genes and susceptibility to immunoglobulin A deficiency and common variable immunodeficiency. J. Clin. Invest. 89:19141922.

4. Cassidy, J. T., G. Oldham, and T. A. E. Platts-Mills. 1979. Functional assessment of a B cell defect in patients with selective IgA deficiency. Clin. Exp. Immunol. 55:296-305.

5. Waldmann, T. A., S. Broder, R. Krukauer, M. Durm, B. Meade, and C. Goldman. 1976. Defect in IgA secretion and in IgA specific suppressor cells in patients with selective IgA deficiency. Trans. Assoc. Phys. 89:215-244.

6. Inoue, T., H. Okubo, J. Kudo, T. Ikuta, K. Hachimine, R. Shibata, O. Yoshinari, K. Fukada, and T. Yanase. 1984. Selective IgA deficiency: Analysis of Ig production in vitro. J. Clin. Immunol. 4:235-241.

7. Mitsuya, H., S. Tomino, S. Hisamitsu, and S. Kishimoto. 1979. Evidence for the failure of $\operatorname{IgA}$ specific $\mathrm{T}$ helper activity in a patient with immunodeficiency with hyper IgM. J. Clin. Lab. Immunol. 2:337-342.

8. Conley, M. A., and M. D. Cooper. 1981. Immature IgA B cells in IgAdeficient patients. N. Engl. J. Med. 305:495-497.

9. Banchereau, J., P. de Paoli, A. Vallé, E. Garcia, and F. Rousset. 1991. Long term human B cell lines dependent on interleukin 4 and anti-CD40. Science (Wash. DC). 251:70-72.

10. Rousset, F., E. Garcia, and J. Banchereau. 1991. Cytokine-induced proliferation and immunoglobulin production of human B lymphocytes triggered through their CD40 antigen. J. Exp. Med. 173:705-710.

11. Rousset, F., E. Garcia, T. Defrance, C. Péronne, N. Vezzio, D. H. Hsu, R. Kastelein, K. W. Moore, and J. Banchereau. 1992. Interleukin 10 is a poten growth and differentiation factor for activated human B lymphocytes. Proc. Natl. Acad. Sci. USA. 89:1890-1893.

12. Defrance, T., B. Vanbervliet, F. Brière, I. Durand, F. Rousset, and J. Banchereau. 1992. Interleukin 10 and Transforming Growth Factor $\beta$ cooperate to induce anti-CD40-activated naive human B cells to secrete Immunoglobulin A. J. Exp. Med. 175:671-682.

13. Spriggs, M. K., R. J. Armitage, L. Strockbine, K. N. Clifford, B. M Macduff, T. A. Sato, C. R. Maliszewski, and W. C. Fanslow. 1992. Recombinan human CD40 ligand stimulates B cell proliferation and immunoglobulin E secretion. J. Exp. Med. 176:1543-1550.

14. Armitage, R. J., T. A. Sato, B. M. Macduff, K. N. Clifford, A. R. Alpert, C. A. Smith, and W. C. Fanslow. 1992. Identification of a source of biologically active CD40 ligand. Eur. J. Immunol. 22:2071-2076.

15. Chevet, D., G. Rifle, M. Guiguet, J. M. Chalopin, Y. Tanter, C. Mousson, and J. M. Rebibou. 1993. Acquired selective immunoglobulin A deficiency in renal transplant recipients. Trans. Proc. 25:1355-1358.
16. Vallé, A., C. E. Zuber, T. Defrance, O. Djossou, M. De Rie, and J. Banchereau. 1989. Activation of human B lymphocytes through CD40 and interleukin 4. Eur. J. Immunol. 19:1463-1467.

17. Peltz, G. A., M. L. Trounstine, and K. W. Moore. 1988. Cloned and expressed human Fc receptor for IgG mediates anti-CD3 dependent lymphoproliferation. J. Immunol. 141:1891-1896.

18. Defrance, T., B. Vanbervliet, J. P. Aubry, Y. Takebe, N. Arai, A. Miyajima T. Yokota, T. Lee, K. Arai, J. E. de Vries, and J. Banchereau. 1987. B cel growth-promoting activity of recombinant human interleukin-4. J. Immunol. 139:1135-1141.

19. Chrétien, I., J. Pène, F. Brière, R. De Waal Malefyt, F. Rousset, and J. E. De Vries. 1990. Regulation of human IgE synthesis. I. Human IgE synthesis in vitro is determined by the reciprocal antagonistic effects of IL-4 and IFN- $\gamma$. Eur. J. Immunol. 20:243-251.

20. Favre, C., J. Wijdenes, H. Cabrillat, O. Djossou, J. Banchereau, and J. E. De Vries. 1989. Epitope mapping of recombinant human gamma interferon using monoclonal antibodies. Mol. Immunol. 26:17-25.

21. Burdin, B., C. Péronne, J. Banchereau, and F. Rousset. 1993. EpsteinBarr virus-transformation induces B lymphocytes to produce human interleukin10. J. Exp. Med. 177:295-304.

22. Plebani, A., A. G. Ugazio, A. M. Avanzini, P. Massimi, L. Zonta, V. Monafo, and G. R. Burgio. 1989. Serum IgG subclass concentrations in healthy subjects at different ages: Age-normal percentile charts. Eur. J. Pediatr. 149:164 167.

23. Chomarat, P., M.-C. Rissoan, J. Banchereau, and P. Miossec. 1993. Interferon $\gamma$ inhibits interleukin-10 production by monocytes. J. Exp. Med. 177:523527.

24. Islam, K. B., L. Nilsson, P. Sideras, L. Hammarström, and C. I. E. Smith 1991. TGF- $\beta 1$ induces germ-line transcripts of both IgA subclasses in human B lymphocytes. Int. Immunol. 3:1099-1106.

25. Zielen, S., P. Bauscher, D. Hofmann, and S. C. Meuer. 1993. Interleukin 10 and immune restoration in common variable immunodeficiency. Lancet 342:750-751

26. Zielen, S., P. Sehrt, J. Rahmig, D. Hofmann, F. Brière, and S. C. Meuer. 1994. Rekonstitution der Immunglobulinproduktion bei patienten mit variablem immundefektsyndrom (CVI) durch das CD40-system und IL-10. Immun. Infekt. 22:24-25.

27. Nonoyama, S., M. Farrington, H. Ishida, M. Howard, and H. D. Ochs 1993. Activated B cells from patients with common variable immunodeficiency proliferate and synthesize immunoglobulin. J. Clin. Invest. 92:1282-1287.

28. Ishida, H., R. Hastings, L. Thompson-Snipes, and M. Howard. 1993. Modified immunological status of anti-IL-10 treated mice. Cell. Immunol. 148:371-384.

29. Bendtzen, K., M. Svenson, V. Jonsson, and E. Hippe. 1990. Autoantibodies to cytokines: Friends or foes? Immunol. Today. 11:167-169.

30. Panem, S., J. I. Check, D. Henriksen, and J. Vilcek. 1982. Antibodies to $\alpha$-interferon in a patient with systemic lupus erythematosus. J. Immunol. 129:1-3.

31. Fong, Y., K. J. Tracey, L. L. Moldawer, D. G. Hesse, K. B. Manogue J. S. Kenney, A. T. Lee, G. C. Kuo, A. C. Allison, S. F. Lowry, and A. Cerami. 1989. Antibodies to cachectin/tumor necrosis factor reduce interleukin $1 \beta$ and interleukin 6 appearance during lethal bacteremia. J. Exp. Med. 170:1627-1633.

32. Panem, S. 1984. Antibodies to interferon in man. Interferon. 2:175-183.

33. Aucouturier, P., M. Mariault, C. Lacombe, and J. L. Preud'homme. 1992. Frequency of selective IgG subclass deficiency: a reappraisal. Clin. Immunol. Immunopathol. 63:289-291.

34. Brière, F., C. Servet-Delprat, J.-M. Bridon, J.-M. Saint-Rémy, and J. Banchereau. 1994. Human interleukin 10 induces naive $\operatorname{sIgD}^{+} \mathrm{B}$ cells to secrete $\mathrm{IgG}_{1}$ and $\mathrm{IgG}_{3}$. J. Exp. Med. 179:757-762.

35. Korthäuer, U., D. Graf, H. W. Mages, F. Brière, M. Padayachee, S. Malcolm, A. G. Ugazio, L. D. Notarangelo, R. J. Levinsky, and R. A. Kroczek. 1993. Defective expression of T-cell CD40 ligand causes X-linked immunodeficiency with hyper-IgM. Nature (Lond.). 361:539-541.

36. DiSanto, J. P., J. Y. Bonnefoy, J. F. Gauchat, A. Fischer, and G. de Saint Basile. 1993. CD40 ligand mutations in X-linked immunodeficiency with hyperIgM. Nature (Lond.). 361:541.

37. Aruffo, A., M. Farrington, D. Hollenbaugh, X. Li, A. Milatovich, S. Nonoyama, J. Bajorath, L. S. Grosmaire, R. Stenkamp, M. Neubauer, R. L. Roberts, R. J. Noelle, J. A. Ledbetter, U. Francke, and H. D. Ochs. 1993. The CD40 ligand, gp39, is defective in activated $\mathrm{T}$ cells from patients with X-linked hyper-IgM syndrome. Cell. 72:291-300.

38. Allen, R. C., R. J. Armitage, M. E. Conley, H. Rosenblatt, N. A. Jenkins N. G. Copeland, M. A. Bedell, S. Edelhoff, C. M. Disteche, D. K. Simoneaux W. C. Fanslow, J. Belmont, and M. K. Spriggs. 1993. CD40 ligand gene defects responsible for X-linked hyper-IgM syndrome. Science (Wash. DC). 259:990. 